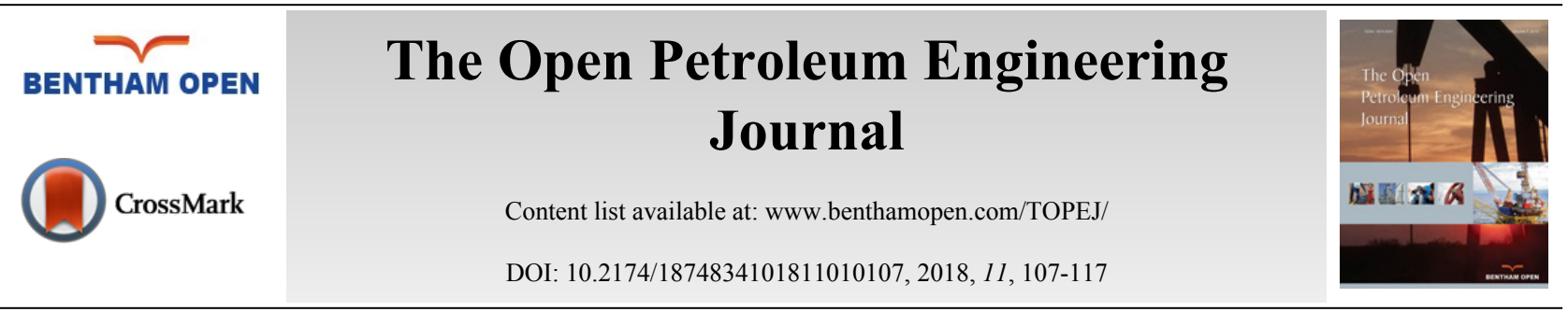

RESEARCH ARTICLE

\title{
Experimental Study of the Contamination Effects of Gachsaran Formation Fluid on the Heavy-weight Drilling Fluid
}

\author{
Naeimavi Majid ${ }^{1}$, Khazali Fereydoon ${ }^{1}$, Abdideh Mohammad ${ }^{2, *}$ and Zohreh Saadati $^{1}$ \\ ${ }^{I}$ Department of Chemistry, Omidiyeh Branch, Islamic Azad University, Omidiyeh, Iran \\ ${ }^{2}$ Department of Petroleum Engineering, Omidiyeh Branch, Islamic Azad University, Omidiyeh, Iran
}

Received: June 26, 2018

Revised: September 11, 2018

Accepted: September 22, 2018

\section{Abstract:}

\section{Introduction:}

Gachsaran Formation is the cap rock of Asmari oil reservoir located in southwestern of Iran. The formation consists of halite, anhydrite, and tachyhydrite, The most important feature of this formation is the presence of high-pressure fluid.

\section{Method:}

Drilling companies have to use heavy-weighted mud to drill the high-pressure formation. Sometimes the weight of drilling fluid is used, up to $2.65(\mathrm{gr} / \mathrm{cm} 3)$. Although heavy-weight mud prevents formation fluid to flow into the well, it is difficult to maintain and control its properties. If the hydrostatic pressure is insufficient, the formation connate fluid penetrates into the drilling mud and contaminates it.

\section{Result:}

The study found that the symptoms of this contamination lead to an increase in calcium, magnesium, carbonates, and bicarbonates levels, as well as a decrease in $\mathrm{pH}$. The drilling fluid rheology also affected by the contamination.

\section{Discussion:}

Then, method of curing this event is discussed. Prevention, the best treatment for this event was introduced. It was also found that, as soon as contamination signs appear, immediately increase the drilling fluid weight as much as possible, and then adjust the $\mathrm{pH}$ between 10.5 and 11.5. The maintain method described is continued until section drilling ends.

Keywords: Drilling fluid, Contamination, Gachsaran Formation, Heavy-weight mud, Formation fluid, WBM.

\section{INTRODUCTION}

Developed along Zagros Fold-Thrust Belt, Gachsaran Formation hosts important petroleum traps and its depositional environment has been researched by many researchers [ 1 - 5]. The formation has been divided into seven members, namely Member 1 through 7. Member 7 consists of limestone, gray marl, and anhydrite. Member 6 involves a succession of anhydrite, limestone, red marl and rock salt. Member 5 is composed of an alternation between gray and red marls, anhydrite and thinly limestone layers. Member 4 contains thick salt layers alternating with anhydrite, gray marl, and seldom limestone. Member 3 includes anhydrite and thick marl layers. Member 2 comprises rock salt, gray marl, anhydrite, and laminated limestone. Hence, Member 1 is made up of five different evaporitic cycles of marl, anhydrite, bituminous shale, and limestone, with a typical width of $50 \mathrm{~m}$. The latter member covers the Asmari reservoir in the southwest of Iran [6]. The width of the sedimentary formation varies across the area, as shown in

* Address correspondence to this authors at the Department of Chemistry, Islamic Azad University, Omidiyeh Branch, Omidiyeh, Iran; Tel: +989163090470; E-mail: chem.dril12000@gmail.com 
Fig. (1), but total width of the complete series has been approximated to be $1600 \mathrm{~m}$ [7]. Several scenarios have been developed to relieve wellbore closure while drilling salt layers. For example, the traditional strategy has been to drill quickly through the salt and to carefully keep the drilling fluid cool to postpone creep [8]. Reaming and jarring may also be needed in such situations [9]. Oil-based Mud (OBM) inhibits wellbore dissolution but cannot decelerate the wellbore closure unless it is kept cool enough during the circulation [10]. Under-saturated Water-based Mud (WBM) presents a great alternative for penetrating into thin and thick salt layers to mitigate the creep and wellbore closure. Most frequently experienced salts along Gachsaran Formation include halite $(\mathrm{NaCl})$, tachyhydrite $\left(\mathrm{CaCl}_{2} \cdot 2 \mathrm{MgCl}_{2} \cdot 12 \mathrm{H}_{2} \mathrm{O}\right)$ and anhydrite $\left(\mathrm{CaSO}_{4}\right)$. Normally, deposition accumulation follows an opposite trend to that of salt solubility in water. For the salts comprising the Gachsaran Formation, the order of solubility is as follows: tachyhydrite $>$ halite $>$ anhydrite. The formation contains different types of evaporitic salts, including sodium chloride $(\mathrm{NaCl})$, potassium chloride $(\mathrm{KCl})$, calcium chloride $\left(\mathrm{CaCl}_{2}\right)$, and magnesium chloride $\left(\mathrm{MgCl}_{2}\right)$. Accordingly, one may develop a formulation for the drilling fluid by which the dissolution can be avoided. Such a synthetic fluid is preferable over WBM as it is free of water and interferes interfering the salts solubility. With such a synthetic mud, the well caliper is commonly within gauge when compared to the case with saturated water-based fluid. Alternatively, drilling highly flexible evaporites with a synthetic mud may cause wellbore collapse, reaming problems, high torque requirements, well deviation, stuck pipe, and casing collapse. In some instances, the stress developed upon drilling a salty formation caused a stuck bit, mainly through the connections, necessitating the injection of fresh water to have the bit released [11].

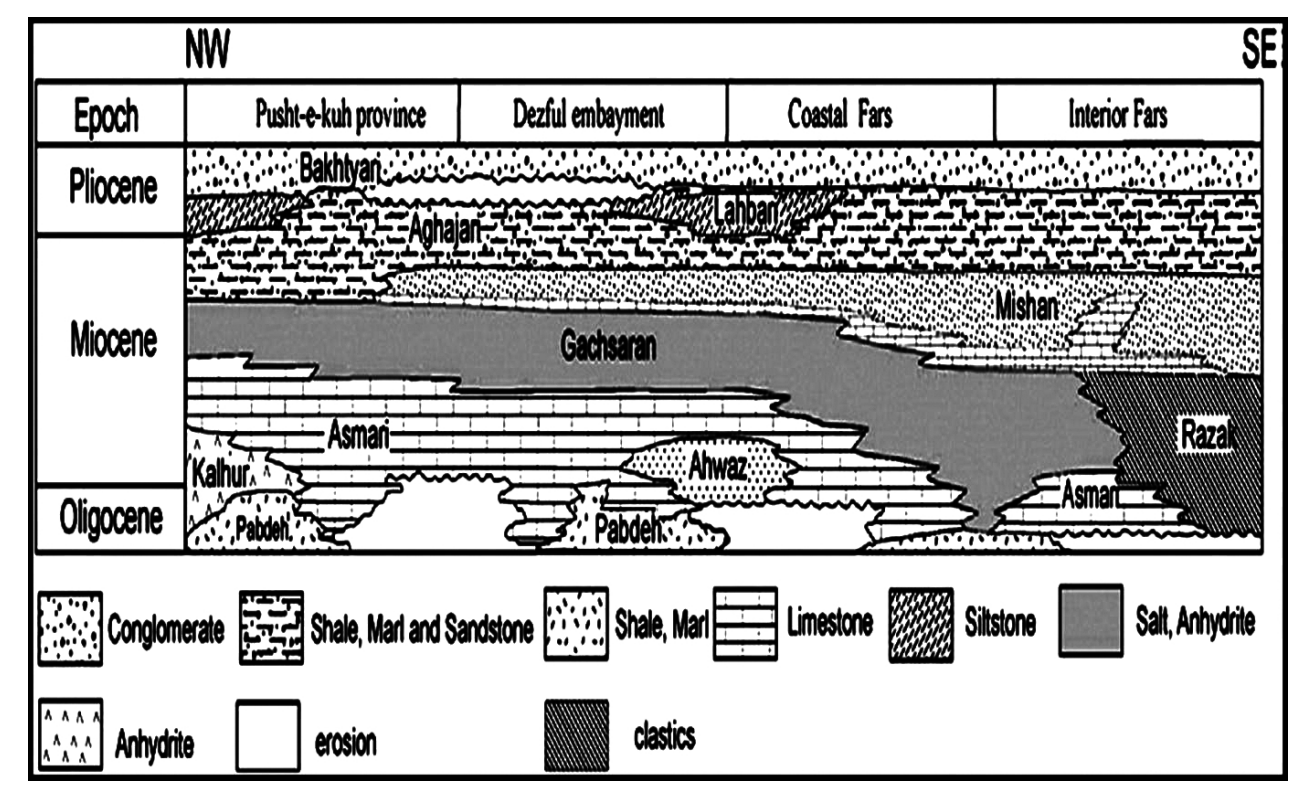

Fig. (1). Stratigraphic correlation of Cenozoic formations within the Zagros Fold-Thrust Belt [12].

In cases where a stream of saltwater flows beneath the salt, there are chances that the mud density decreases upon reaching the base. Thus, it should be kept in mind that, when saltwater is used to drill a salt formation, the salt is not seen as a contaminant, while it is recognized as a contaminant with freshwater muds. Chaney P.E [13] explained that, besides solid salt particles and salt water, seawater has been recognized as a significant source of contaminants as it contains magnesium $\left(\mathrm{Mg}^{2+}\right)$ and calcium $\left(\mathrm{Ca}^{2+}\right)$ ion along with clay minerals. $\mathrm{Ca}^{2+}$ and $\mathrm{Mg}^{2+}$ ions in seawater are harmful to WBMs. Indeed, at higher $\mathrm{pH}$ values, magnesium and calcium hydroxide are relatively insoluble in water, and application of caustic soda to eliminate magnesium further inhibits calcium dissolution and lime sedimentation. Kumapayi [14] explained that "the Gulf of Mexico seawater requires 4.3 to $5.7 \mathrm{~kg} / \mathrm{m}^{3}$ of caustic soda to precipitate all magnesium. In seawater, the preferred treatment for magnesium removal is caustic soda, while the preferred treatment for calcium removal is soda ash". Ali et al. [15] looked into the result of $\mathrm{NaCl}$ contamination on rheological properties of bentonite-containing mud, concluding that both Plastic Viscosity (PV) and Electrical Resistivity (ES) decrease with a rise in salt content. Basirat et al. [16] carried out similar research and explained that once contaminated, drilling muds tend to exhibit approximately 30\% higher fluid loss along with $86 \%$ lower electrical resistivity. Furthermore, Hassiba and Amani [17] demonstrated that salt contaminants tend to escalate shear stress/shear rate while $\mathrm{KCl}$ contaminants tend to reduce the shear stress/shear rate in WBM. According to Neff [18], the amount or quantity of solid particles, 
such as drill cuttings and formation solids, in the mud vary with a grain size of the rock which is being drilled. Amani et al. [19] investigated the effect of a flow of magnesium-containing saltwater on the performance of drilling mud at elevated temperature in an attempt to evaluate the mud response in down-hole conditions. They showed that, such a flow tends to lower the performance of hematite and barite-containing muds; the finding suggested that saltwater influences the dispersion, hydration, and flocculation behaviors of the weighting and viscosifier agents, creating particles dispersion and increasing the number of specific platelets in the suspension system, thereby making the mud inadequate for carrying the cuttings. However, ferrobar mud could retain the cutting in the suspensions with a flow of magnesium saltwater at enhanced temperature. Adekomaya O.A [20]. and Sami N.A [21]. reviewed previous studies and discovered that rheological and filtration properties (and hence efficiency) of drilling fluid are damaged by magnesium ion contamination, as indicated by reduced Plastic Viscosity (PV), Yield Point (YP), and gel strength. Also, magnesium ion was found to increase filtration loss volume of the drilling fluid. Indeed, with increasing the concentration of magnesium chloride salt, the fluid loss into the formation raises. Most of the works reviewed aboveexamined clay-containing or low-density WBMs, while Gachsaran Formation is commonly drilled with heavy-weight salt-saturated mud with high sensitivity to treatment and maintenance operations. The present study begins with identifying symptoms leakage of Gachsaran formation fluid into drilling mud. Secondly, the effects of the contamination resulted from such leakage on the drilling fluid are examined in laboratory based on the amounts of different contaminants. Finally, a discussion is presented on the exposure, treatment, and maintenance methods required to continue the drilling operation at minimum damage/cost.

\section{EXPERIMENTAL}

\subsection{Drilling Fluid Design for Salty Layers Containing High-Pressure Formation Fluid}

Gypsum tends to become dehydrated at elevated pressure and temperature, thereby releasing water upon transformation to basanite or anhydrite $\left(\mathrm{CaSO}_{4}\right)$. As an impermeable and compact evaporite, anhydrate can keep up with the excessive pressure of the substrate. Depth factor also results in irregular pressure on specific structural layers. Gachsaran Formation is composed of thick sealing anhydrite layers separating red and grey marls from almost all upper strata and interrupting the fluid interconnection between lower and upper layers. This has brought on that the pore pressure is more affected by the straining pressure rather than the hydrostatic pressure of mud column [22]. Application of unsaturated saltwater-based fluid has been the main workaround for mitigating the problem, respecting the role played by the drilling fluid in the dissolution of the rock [23]. However, when drilling more soluble evaporitic formations, a substantial dissolution of the salt has been observed. Regardless of the dissolution problems, WBMs are still being used in particular applications [24]. The WBMs are less expensive and environmentally green, suggesting heavy-weight salt-saturated WBM to deal with rock salt. The drilling fluid of choice for salt zones along the wells penetrating into Gachsaran Formation has been heavy-weight salt-saturated WBM, so as to minimize salt solubility, prevent formation fluid leakage by over-balancing the mud weight, and control elastic properties of halite through the wellbore.

\subsection{Formation Fluid Contamination}

Local mud engineers refer to heavy-weight salt-saturated mud as "a newborn who needs much care". Due to high solid content along with low water content of such mud, contaminations tend to infect the existing water phase quickly with least dilution. According to a report by National Iranian South Oilfields Company (not published publically), samples taken from several wells penetrating into Gachsaran Formation in southwestern Iran were dry-tested and exhibited average connate water contents tabulated in Table $\mathbf{1 .}$

Table 1. Properties of the fluid taken via drill-stem test in Gachsaran Formation.

\begin{tabular}{|c|c|}
\hline Density & $1.2\left(\mathrm{gr} / \mathrm{cm}^{3}\right)$ \\
\hline $\mathrm{pH}$ & 6.1 \\
\hline Salinity & $296,000(\mathrm{mg} / \mathrm{l})$ \\
\hline Calcium(from anhydrite $/ \mathrm{CaCl} 2)$ & $28,100(\mathrm{mg} / \mathrm{l})$ \\
\hline Magnesium(from $\mathrm{MgCl} 2)$ & $7,600(\mathrm{mg} / \mathrm{l})$ \\
\hline Sulfate(from anhydrite) & $2,000(\mathrm{mg} / \mathrm{l})$ \\
\hline Carbonate & $125(\mathrm{mg} / \mathrm{l})$ \\
\hline Bicarbonate & $75(\mathrm{mg} / \mathrm{l})$ \\
\hline
\end{tabular}


Contaminants of the drilling fluid system in Gachsaran Formation come from a number of sources: drilled salt, anhydrite (gypsum), hard water/salt water flow, carbonates, bicarbonates, calcium, and magnesium. Different contaminants impose different impacts on the mud, thereby necessitating different treatments to prevent subsequent drilling problems [25]. Additionally in Table 2, explained some differences between formation of water and drilling fluid chemical properties.

Table 2. Chemical differences between Gachsaran formation water and drilling fluid that used in Gachsaran section.

\begin{tabular}{|c|c|c|}
\hline Chemical properties & Drilling fluid & Formation fluid \\
\hline Density & variable & $1.2\left(\mathrm{gr} / \mathrm{cm}^{3}\right)$ \\
\hline $\mathrm{pH}$ & $9-10.5$ & 2.1 \\
\hline Salinity & 320,000 & $296,000(\mathrm{mg} / \mathrm{l})$ \\
\hline Calcium(from anhydrite $/ \mathrm{CaCl} 2)$ & $<400$ & $7,600(\mathrm{mg} / \mathrm{l})$ \\
\hline Magnesium(from $\mathrm{MgCl} 2)$ & $<100$ & $2,000(\mathrm{mg} / \mathrm{l})$ \\
\hline Sulfate(from anhydrite) & NIL & $125(\mathrm{mg} / \mathrm{l})$ \\
\hline Carbonate & NIL & $75(\mathrm{mg} / \mathrm{l})$ \\
\hline Bicarbonate & NIL & \\
\hline
\end{tabular}

\subsection{Typicality Case (Well No. \#AZ 509 in Ahwaz Oilfield, Iran)}

In this case, according to the drilling program, sodium chloride-saturated WBM was suggested as drilling fluid for drilling the well interval between seating depths of $12 \frac{1 / 4}{4}$ and $9 \frac{5}{8}$ " casing shoes (the 13 3/8" casing shoe was set into Member 6 of Gachsaran Formation at a depth of $1925 \mathrm{~m}$, and the 9 5/8" casing show was planned to be seated into Member 1 (cap rock) at a depth of $2763 \mathrm{~m}$ ). An expected lithological column of Gachsaran Formation along this well is shown in Table 3. The pore and fracture pressure data provided by the Department of Geology suggested that the expected LOT pressure at the $13 \mathrm{3} / 8$ " casing shoe is $2.08 \mathrm{gr} / \mathrm{cm}^{3}$. The situation suggested the use of $\mathrm{NaCl}$ for saturating the drilling fluid to increase its weight to $1.2 \mathrm{gr} / \mathrm{cm}^{3}$.

Table 3. A lithological column of Gachsaran Formation at Well No. \#AZ 509.

\begin{tabular}{|c|c|c|c|}
\hline Formation & Type & Top(m) & Bottom(m) \\
\hline Gachsaran(member\#7) & Anhydrite/shale/marl & 1825 & 1915 \\
\hline Gachsaran(member\#6) & Anhydrite/shale/marl & 1915 & 2056 \\
\hline Gachsaran(member\#5) & Halite & 2056 & 2299 \\
\hline Gachsaran(member\#4) & Halite & 2299 & 2407 \\
\hline Gachsaran(member\#3) & Anhydrite/marl/ Halite & 2407 & 2606 \\
\hline Gachsaran(member\#2) & Halite & 2606 & 2718 \\
\hline Gachsaran(member\#1) & Shale/limestone/ Anhydrite & 2718 & 2795 \\
\hline
\end{tabular}

The well was planned to go through Gachsaran Formations and reach a total depth of $3255 \mathrm{~m}$ to produce from Asmari limestone reservoir. The composition of the WBM used in the drilling operation is presented in Table $\mathbf{3}$, with an estimated tolerance of properties of this mud displayed in Table 4.

Table 4. The WBM used to drill through Gachsaran Formation (Members 1 - 6) in cased well (mud type: heavy-weight saltsaturated WBM).

\begin{tabular}{|c|c|}
\hline Component & Concentration $\left(\mathbf{K g} / \mathbf{m}^{3}\right)$ \\
\hline Water & As the base of mud \\
\hline Soda ash & $4.3 \mathrm{~kg} / \mathrm{m}^{3}$ \\
\hline Salt(NaCl) & $357 \mathrm{~kg} / \mathrm{m}^{3}$ \\
\hline Starch(modified) & $40 \mathrm{~kg} / \mathrm{m}^{3}$ \\
\hline Barite (barium sulfate) + Fer-o-bar (ferric oxide) & 3 portion barite +1 portion ferobar adding to get requirement density from $2.08\left(\mathrm{gr} / \mathrm{cm}^{3}\right)$ at start, to \\
\hline Caustic soda(NaOH) & $2.40\left(\mathrm{gr} / \mathrm{cm}^{3}\right)$ at finale hole drilling \\
\hline Natural Gum & $0.28 \mathrm{~kg} / \mathrm{m}^{3}$ \\
\hline & $11 \mathrm{~kg} / \mathrm{m}^{3}$ \\
\hline
\end{tabular}

As seen from Table 5, along Gachsaran Formation (Members 5-2, basically composed of a halite), the mud weight was increased to $2.08 \mathrm{gr} / \mathrm{cm}^{3}$ to prevent wellbore collapse. 
Table 5. Estimated tolerance of drilling fluid properties according to the well drilling program.

\begin{tabular}{|c|c|c|c|c|c|c|c|c|}
\hline $\begin{array}{c}\text { Mud Weight } \\
\left(\mathbf{g r} / \mathbf{c m}^{\mathbf{3}}\right)\end{array}$ & $\begin{array}{c}\text { PV } \\
\text { (Plastic Viscosity) } \\
\text { (mP.s) }\end{array}$ & $\begin{array}{c}\text { YP } \\
\text { (Yield Point) } \\
(\mathbf{P a})\end{array}$ & $\begin{array}{c}\text { MF (Marsh } \\
\text { Funnel) (S) }\end{array}$ & Salinity (mg/l) & pH & Gel 10' (Pa) & Gel 10” (Pa) & $\begin{array}{c}\text { API F.L. (fluid } \\
\text { loss) (ml) }\end{array}$ \\
\hline $2.08-2.40$ & $45-55$ & $2-53$ & $50-70$ & 320,000 & $9.5-10.5$ & $8.5-12.7$ & $12.7-17$ & $0-2$ \\
\hline
\end{tabular}

\section{MATERIAL AND METHODS}

\subsection{Material and Apparatus}

In order to develop analytical methods for studying the effect of possible interfering ions on drilling fluid performance, formation fluids shall be prepared synthetically. Preparation of fairly stable synthetic hard water involves mixing distilled water with the considered ions according to Table 1. All of the materials used for this purpose were provided by Merck. Once prepared, the fluid was analyzed to compare its properties with those of original formation fluid. All additives (commercial grades) were supplied by National Iranian South Oilfield Company (Ahwaz, Iran) through National Iranian Drilling Company. Table $\mathbf{2}$ shows the composition of the formulated drilling muds.

The rheological determination was made on the prepared fluids, wherein viscosity, gel strength, and yield point were measured using a six-speed viscometer (Model 35 SA fann USA) that could measure single or multi-point viscosity. Plastic viscosity and yield point were calculated as follows:

$$
\begin{gathered}
\text { Plastic Viscosity }(\mathrm{mPa} . \mathrm{s})=\text { reading at } 600 \mathrm{rpm} \text { - reading at } 300 \mathrm{rpm} \\
\text { Yield Point in }(\mathrm{Pa})=\text { reading at } 300 \mathrm{rpm} \text { - Plastic Viscosity }
\end{gathered}
$$

In this research, $\mathrm{pH}$ was measured by a Jenway digital $\mathrm{pH}$ meter. A multi-mixer manufactured by Fann was used to mix the drilling fluids. Mud densities were determined through mud balance. A standard API filter press was used to determine the filtration and filter cake building characteristics of the drilling fluids. Total filtration area was $7.1( \pm 0.1)$ $i^{2}$. A filtrate analysis kit was utilized to evaluate necessary chemical parameters such as the contents of chloride, $P_{f}, M_{f}$, calcium, and magnesium according to Recommended Practice for Field Testing Water-based Drilling Fluids [26].

Notice that, given that the mud samples were salt-saturated $(320,000 \mathrm{mg} / \mathrm{l} \mathrm{of} \mathrm{Cl-})$ and no lime was added to the mud mixes, chloride and $\mathrm{P}_{\mathrm{m}}$ (lime content) measurements were not required.

\subsection{Experimental Method}

In order to determine effects of variable amounts of different contaminations on the heavy-weight mud properties, each of the prepared drilling fluid samples (with average densities ranging from 2.08 to $2.4 \mathrm{gr} / \mathrm{cm}^{3}$ ) was used to drill the hole, followed by adding the synthetic formation fluid at various concentrations: $5 \% \mathrm{v} / \mathrm{v}, 7 \% \mathrm{v} / \mathrm{v}, 9 \% \mathrm{v} / \mathrm{v}, 10 \% \mathrm{v} / \mathrm{v}$, $12 \% \mathrm{v} / \mathrm{v}, 14 \% \mathrm{v} / \mathrm{v}, 15 \% \mathrm{v} / \mathrm{v}, 17 \% \mathrm{v} / \mathrm{v}, 19 \% \mathrm{v} / \mathrm{v}, 20 \% \mathrm{v} / \mathrm{v}$. The mud properties were determined both before and after the addition under room condition. The experiment was carried out in phases with a mud volume of $350 \mathrm{~cm}^{3}$. Rheological measurements were performed on the fluids according to the API-certified procedure for WBM testing to evaluate their viscosity, gel strength, and yield point. Results of the test indicated the relationship between mud properties and the contaminant content.

Please remind that the introduction of the formation fluid into the mud reduces its density, in proportion to the added amount of the formation fluid. To compensate for this effect, mud weight was increased to the original value upon adding the formation fluid.

\section{RESULTS AND DISCUSSION}

\subsection{Effect of Formation Fluid on Mud Rheology}

Figs. (2 and 3) show the effects of concentration of the contaminants on PV(Plastic Viscosity), apparent viscosity, YP(Yield Point), and gel strength. On the plot of YP, rheological properties increase at contaminant concentrations of $5 \%$ and $7 \%$, due to low $\mathrm{pH}$ values and accretion of trace clay in the mud at lower formation fluid concentration. At higher hardness and contaminant concentration, however, the rheological properties (YP and gel strength) dropped rapidly upon small fluctuations in PV. Apparent viscosity was seen to be directly dependent on the concentration of the contaminants because all ion contents of the formation fluid were affected by trace amounts of clay in the mud, thereby reducing the $\mathrm{pH}$ value. Many of natural polymers are also sensitive to calcium. Gums (e.g. guar/natural gum) are 
sensitive to calcium and should not be used where calcium concentration exceeds $250 \mathrm{mg} / \mathrm{l}$. Of the commonly used polymers, only starch and HEC perform well at high calcium concentrations [27].

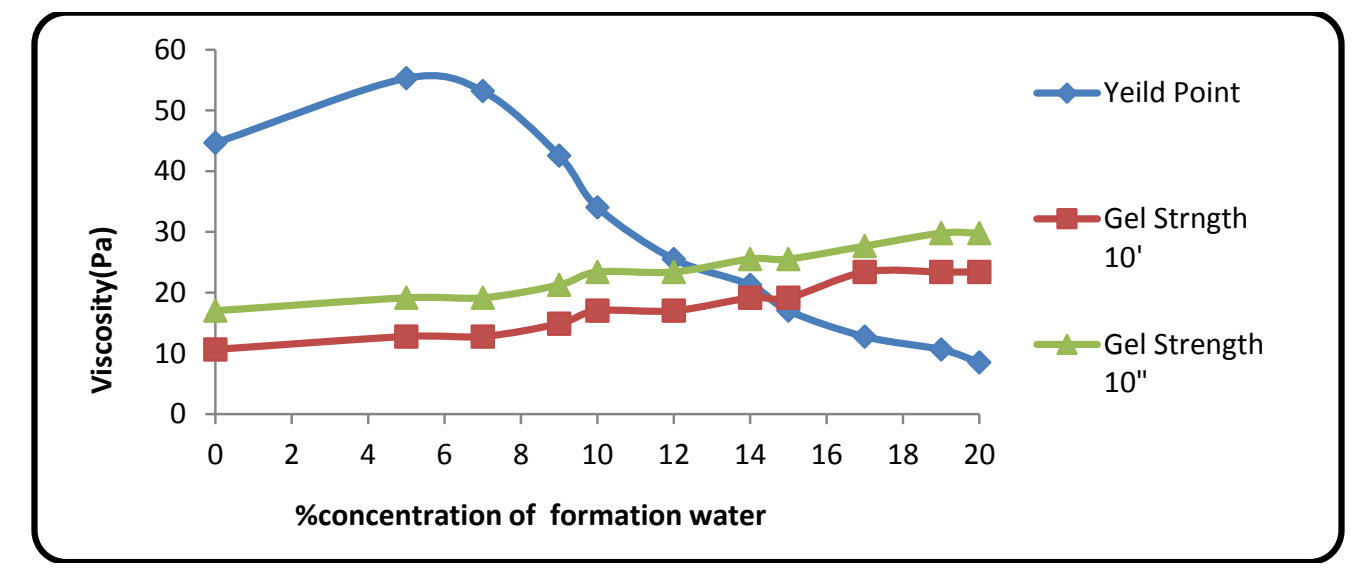

Fig. (2). YP and gel strength variations with contaminant concentration.

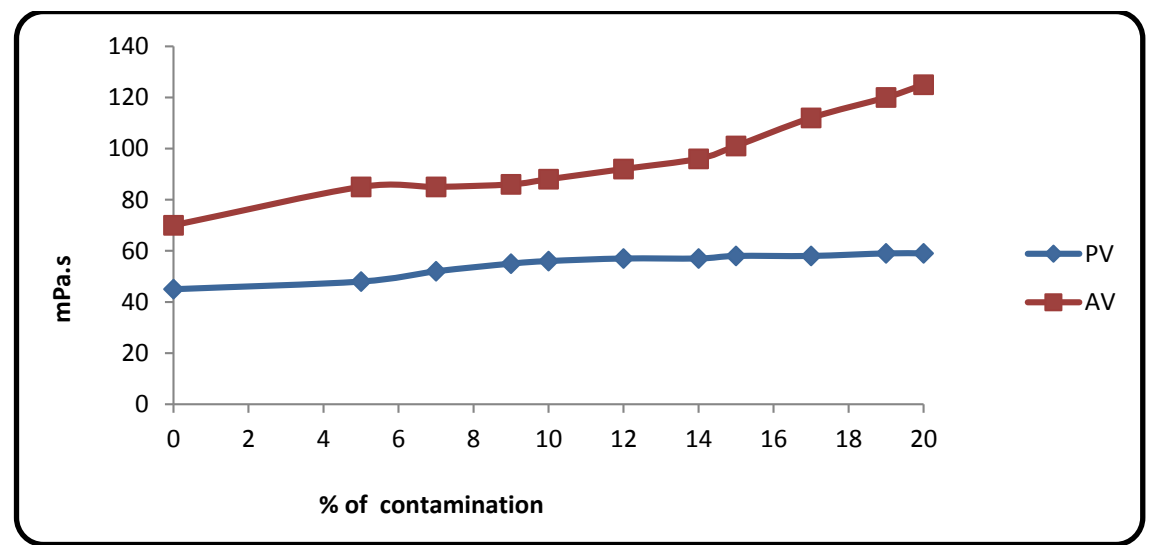

Fig. (3). PV and apparent viscosity variations with contaminant concentration.

\subsection{Effect of Formation Fluid on Fluid Loss and Cake Thickness}

Figs. (4 and 5) show the values of fluid loss at 10 different concentrations of the contaminants. The plots show that the fluid loss grows rapidly with contaminant concentration, thereby intensifying the interaction between calcium/magnesium ion with polymers [27].

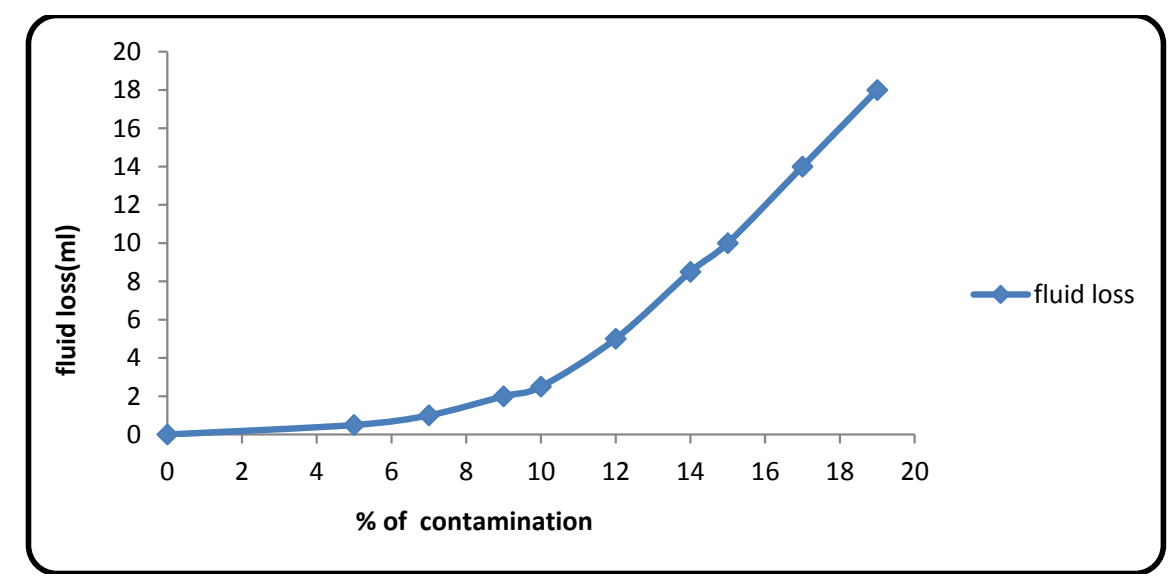

Fig. (4). Fluid loss variations with contaminant concentration. 


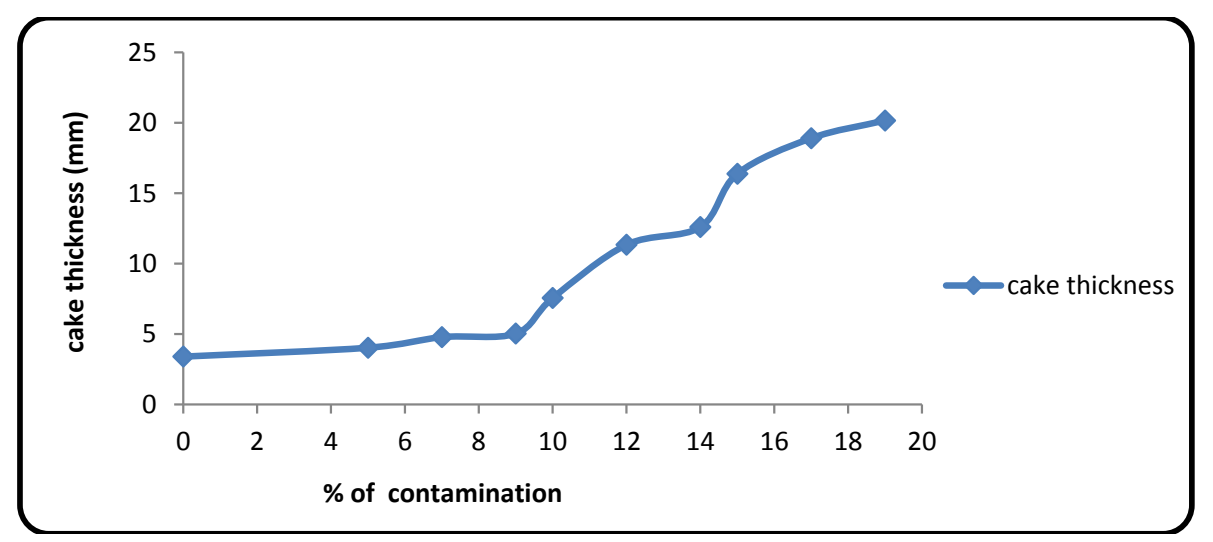

Fig. (5). Cake thickness variations with contaminant concentration.

\subsection{Effect of Formation Fluid on $P_{f}$ and $M_{f}$}

Considering the presence of carbonates and bicarbonates in Gachsaran Formation fluid (Table 1), one must study variations of these anions in the mud. When contaminant concentration was $10 \%, \mathrm{P}_{\mathrm{f}}$ factor tended to zero because increasing contaminate value same $\mathrm{Mg}^{2+}$ spend initial $\mathrm{NaOH}$ in the mud. Therefore, beyond this point, the alkalinity of the mud was originated from $\mathrm{CO}_{3}$ - and $\mathrm{HCO}_{3}$ - (Figs. 6 and 7).

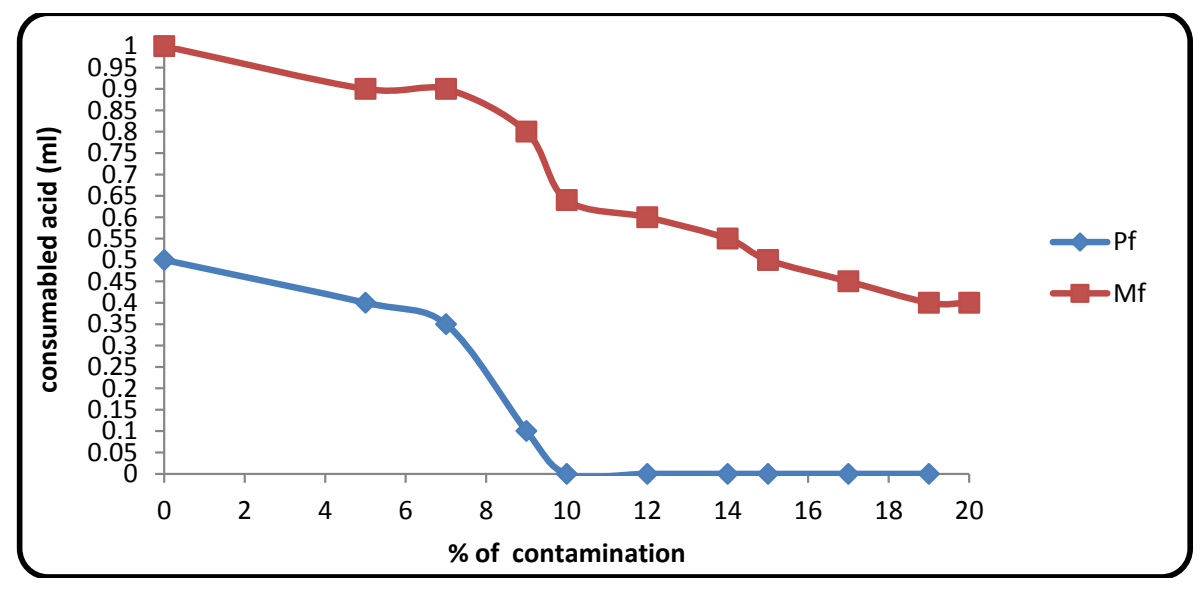

Fig. (6). Variations of $P_{f}, M_{f}$ fluctuation with contaminant concentration.

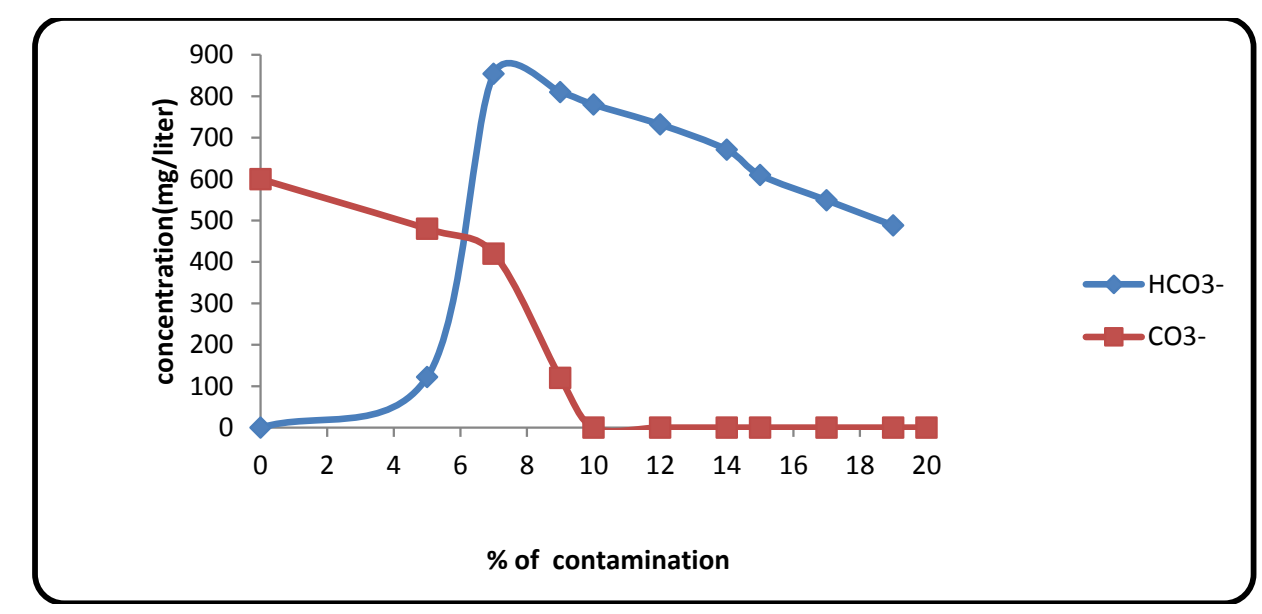

Fig. (7). Variations of carbonate/bicarbonate contents with contaminant concentration. 


\subsection{Effect of Formation Fluid on pH}

The value of $\mathrm{pH}$ decreased with increasing the amount of formation fluid in the mud (Fig. 8). $\mathrm{Mg}^{2+}, \mathrm{Ca}^{2+}$ and sulfate ions are known to decrease the $\mathrm{pH}$ value.

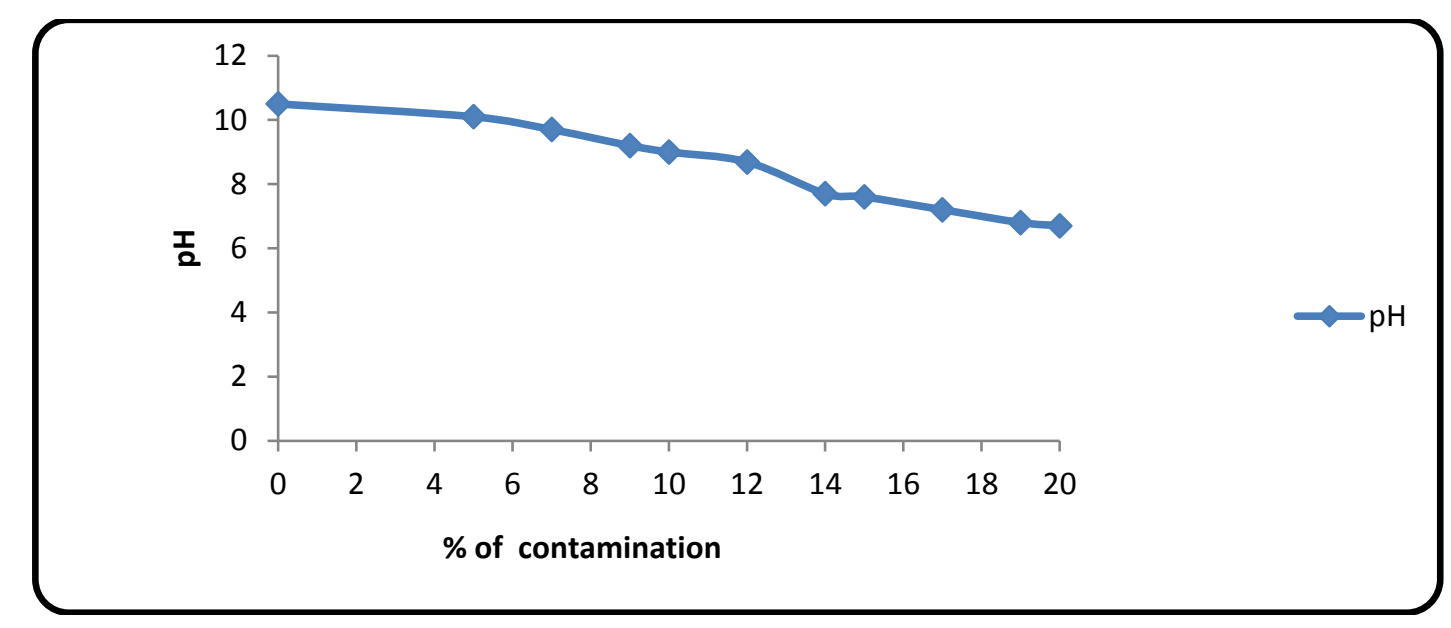

Fig. (8). Variations of $\mathrm{pH}$ alteration with contaminant concentration.

\subsection{Effect of Formation Fluid on Hardness, $\mathrm{Ca}^{2+,}$ and $\mathrm{Mg}^{2+}$}

Fig. (9) shows an influx of formation fluid with increasing the hardness of the drilling fluid. The small fluctuations in magnesium concentration in the initial segment of the plot were caused by the presence of caustic soda in the formulated mud. Upon consumption of caustic soda by connate elements of the formation fluid, the magnesium ion content of the drilling mud increased rapidly.

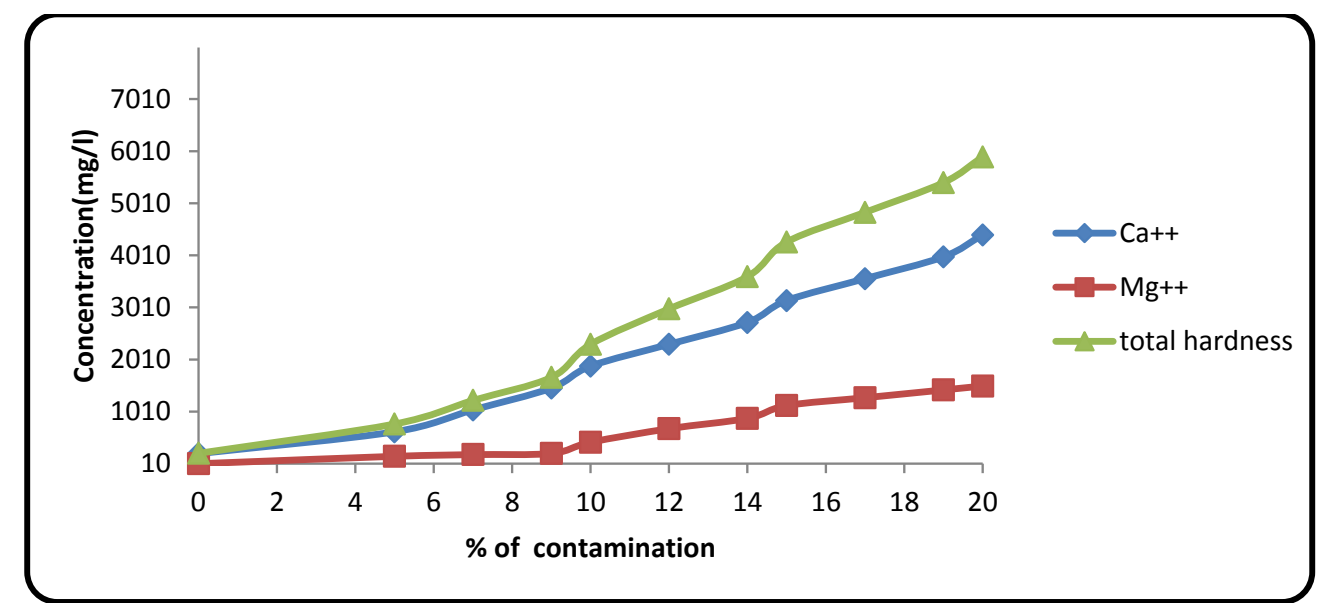

Fig. (9). Effect of formation fluid on total hardness and $\mathrm{Ca}^{2+}$ and $\mathrm{Mg}^{2+}$ contents.

\section{MUD PROPERTIES TREATMENT AFTER CONTAMINATION}

Soda ash is normally used to precipitate calcium. Accordingly, $2.85 \mathrm{~kg}$ of soda ash per $\mathrm{m}^{3}$ of fluid will precipitate $1078 \mathrm{mg} / \mathrm{l}$ of calcium. To maintain a constant $\mathrm{pH}$ while precipitating $\mathrm{CO}_{3}$ and $\mathrm{HCO}_{3}$, when $\mathrm{pH}$ of the mud exceeds 10.5 , the entire deal of magnesium has been essentially precipitated as magnesium hydroxide. Small daily additions of lime will be required for this purpose. $\mathrm{pH}$ of the mud should be maintained between 11.0 and 11.5 to keep most of the existing carbonates in the mud in the form of $\mathrm{CO}_{3}$ rather than the more adverse $\mathrm{HCO}_{3}$. By maintaining the $\mathrm{pH}$ value using lime and caustic soda, the total content of carbonates can be minimized. Table 6 showed that $\mathrm{pH}$ adjustment with lime and caustic soda may be helpful for continuing the drilling, although the drilling fluid properties were not recovered satisfactorily. 
Table 6. Contaminated mud treated with caustic soda and lime.

\begin{tabular}{|c|c|c|c|}
\hline Drilling Fluid Properties (unit) & Before Contamination & After $20 \%$ v Contamination & $\begin{array}{l}\text { After treatment by lime and caustic to adjust the } \mathrm{pH} \\
\text { between } 10.5-11.5\end{array}$ \\
\hline P.V (m.Pa.s) & 45 & 59 & 62 \\
\hline A.V (m.Pa.s) & 70 & 125 & 128 \\
\hline Y.P (Pa) & 44 & 8.5 & 22 \\
\hline Gel strength $10^{\prime}(\mathrm{Pa})$ & 10 & 23 & 12 \\
\hline Gel strength $10 ”(\mathrm{~Pa})$ & 17 & 29 & 20 \\
\hline $\mathrm{Ca}^{2++}(\mathrm{mg} / \mathrm{lit})$ & 200 & 4400 & 6800 \\
\hline $\mathrm{Mg}^{2++}(\mathrm{mg} / \mathrm{lit})$ & 10 & 1500 & 150 \\
\hline Total hardness (mg/lit) & 210 & 5900 & 6950 \\
\hline Fluid loss(ml) & 0 & 18 & 8 \\
\hline Cake thickness (mm) & 3.5 & 20 & 9 \\
\hline $\mathrm{P}_{\mathrm{f}}(\mathrm{ml}$ of acid $)$ & 0.5 & 0 & 1 \\
\hline $\mathrm{M}_{\mathrm{f}}(\mathrm{ml}$ of acid $)$ & 1 & 0.4 & 1.5 \\
\hline HCO3- (mg) & 0 & 488 & 42 \\
\hline $\mathrm{CO} 3-(\mathrm{mg})$ & 600 & 0 & 255 \\
\hline $\mathrm{pH}$ & 10.5 & 6.7 & 11.5 \\
\hline
\end{tabular}

\section{CONCLUSION}

When formation fluid (water) leaked in well and the drilling fluid contaminated, mud properties such as Plastic viscosity, Appearance viscosity, Yield point, Gel strength, Cake thickness, total hardness and fluid loss increased, additionally the $\mathrm{pH}$ is decreased.

Prevention has been proved to be superior to cure. When the formation fluid leakage symptoms are observed in a drilling fluid, mud weight must be increased to stop the leakage. Both pre-treatment and regular checking of the mud in the mud tanks help identifies mud contamination promptly. However, the following can be used to treat and maintain contaminated drilling fluids:

- Adding caustic soda to raise $\mathrm{pH}$ beyond 10.5 and have $\mathrm{Mg}^{2+}$ precipitated.

- Adding soda ash to eliminate $\mathrm{Ca}^{2+}$ according to the proposed formula.

- Adding lime to prevent contamination resulted from $\mathrm{HCO}_{3}$ - and $\mathrm{CO}_{3}^{-}$.

A number of methods have been proposed to treat the contaminations, as mentioned in sections of drilling handbooks on drilling fluid maintenance, including the use of gypsum- or carbonate-based mud. However, such methods work light-weight muds for clay rather than heavy-weight salt-saturated muds [27, 28].

- Lignosulfonate can be added to improve mud rheology. Increased contents of calcium, magnesium, carbonate and bicarbonate ions and decreased value of $\mathrm{pH}$ were identified as symptoms of formation fluid leakage into drilling fluid in Gachsaran Formation. The best treatment was found to be prevention measures.

- Adding low amounts of lime to the mud pit to control its $\mathrm{pH}$ value under 11.

- Moreover, caustic soda and lime can be added to retain $\mathrm{pH}$ value between 10.5 and 11.5; over-treating with soda ash for removing $\mathrm{Ca}^{2++}$ may increase the contents of carbonate and bicarbonate ions in drilling fluid.

\section{CONSENT FOR PUBLICATION}

Declared none.

\section{CONFLICT OF INTEREST}

The authors declare no conflict of interest, financial or otherwise. 


\section{ACKNOWLEDGEMENTS}

Declared none

\section{REFERENCES}

[1] C.A.E. O’Brien, "Salt diapirism in South Persia", Geol. Mijnb., vol. 19, pp. 337-376, 1957.

[2] N.J. Falcon, "The geology of the north-east margin of the Arabian basement shield. Adv. Sci. 24: 31-42", In: Fuh S C 2000.

[3] W.D. Gill, and M.A. Ala, "Sedimentology of gachsaran formation (lower fars series)", Southwest Iran. AAPG Bull, vol. 56, pp. 1965-1975, 1972 .

[4] M.S. Kashfi, "Stratigraphy and environmental sedimentology of the Lower Fars Group (Miocene), south-southwest Iran", AAPG Bull., vol. 64, pp. 2095-2107, 1980.

[5] A. Bahroudi, and H.A. Koyi, "Tectonic-sedimentary framework of Gachsaran Formation in the Zagros foreland basin", Mar. Pet. Geol., vol. 21, pp. 1295-1310, 2004. [http://dx.doi.org/10.1016/j.marpetgeo.2004.09.001]

[6] A.S. Alsharhan, and A.E.M. Nairn, Sedimentary basins and petroleum geology of the Middle East., Elsevier: Amsterdam, 1997.

[7] H. Motiei, Geology of Iran, Stratigraphy of Zagros., Geology Organization of Iran: Tehran, 1973.

[8] M.B. Dusseault, V. Maury, F. Sanfilippo, and F.J. Santarelli, Drilling through salt: Constitutive behavior and drilling strategies, American Association of Rock Mechanics, North American Rock Mechanics Association, 04-608, pp. 1-13, 2004.

[9] C. Chatar, S. Mohan, and M. Imler, "Overcoming a difficult salt drilling environment in the Gulf of Mexico: A case study", In: Paper IADC/SPE 128192 presented at the IADC/SPE Drilling Conference and Exhibition, New Orleans, LA, USA, 2010, pp. 1-12.

[10] M.B. Dusseault, M.N. Gray, and P.A. Nawrocki, "Why Oil wells Leak: Cement behavior and long-term consequences, SPE 64733 presented at the SPE international oil and gas conference and exhibition", Beijing, China, 2000

[11] R.F.T. Lomba, G.T. Teixeira, R.R. Pessanha, B.S. Lomba, and M.G. Folsta, "Cardoso Jr, and Gonçalves J. T. lessons learned in drilling presalt Wells with water based muds, petrobras", Offshore Technology Conference, 2013

[12] G.A. James, and J.G. Wynd, "Stratigraphic nomenclature of Iranian oil consortium agreement area", $A A P G$ Bull., vol. 49, pp. 2182-2245, 1965.

[13] P.E. Chaney, "A Review of recent advances in drilling mud control, Drilling and Production Practice", American Petroleum Institute, pp. $31-46,1942$.

[14] Y. Kumapayi, K. Bello, O. Adekomaya, A. Akintola, J. Dala, I. Mohammed, and O. Olafuyi, "Investigating the Effects of Contaminants on the performance of Oil-Based Invert Emulsion Drilling Fluid", Pet. Technol. Dev. J., vol. 2, pp. 60-74, 2014.

[15] K. Ali, C. Vipulanandan, and D. Richardson, "Salt contamination on the resistivity and plastic viscosity of a bentonite drilling mud", Proceedings of CIGMAT Conference \& Exhibition, 2013

[16] B. Basirat, C. Vipulanandan, and D. Richardson, "Equivalent resistance of a 3-D conductive medium", Proceedings of THC-IT Conference \& Exhibition, 2013

[17] K J. Hassiba, and M. Amani, The effect of salinity on the rheological properties of water based mud under high pressures and high temperatures for drilling offshore and deep wells earth science research; Vol. 2, 12013.

[18] J.M. Neff, Composition., Environmental fates and biological effect of water based drilling mud and cuttings discharged to the marine environment, 2005, p. 17.

[19] M. Amani, and J.H. Khaled, "Salinity Effect on the Rheological Properties of Water Based Mud under High Pressures and High Temperatures of Deep Wells, SPE-163315-MS presented at SPE Kuwait International Petroleum Conference and Exhibition, 10-12 December", Kuwait City, Kuwait, 2012

[20] O. Adekomaya, "Olufemi. A., Olalekan O. an experimental study of the effect of contaminants on the flow properties of oil-based drilling mud", J. Pet. Coal, vol. 53, no. 4, pp. 315-319, 2011.

[21] N. A. Sami, "Effect of magnesium salt contamination on the behavior of drilling fluids", Egypt. J. Pet., 2012.

[22] H. Rabia, Well engineering and construction, Entrac Consulting P-1-49, 789P (2001).

[23] J.S. Sheffield, K.B. Collins, and R.M. Hackney, Salt Drilling in the Rocky Mountains, 1983. [http://dx.doi.org/10.2118/11374-MS]

[24] S.M Stash, M.E. Jones, and B. Williston, An Analysis of Salt Drilling Techniques for Brine-Based Drilling-Fluid Systems, SPE Drilling Engineering, 1988.

[25] Drilling Fluids Manual, Amoco Production Company, six ed., 1994.

[26] ANSI/API RECOMMENDED PRACTICE 13B-1., Recommended Practice for Field Testing Water-based Drilling Fluids, Fourth Edition, March 2009 Errata 1, August 2014. 
[27] M.R. Annis, and V.S Martin, Drilling fluids technology., Exxon Company: U.S.A, 1974.

[28] Drilling Fluids Reference Manual, Baker Hughes., Revision, 2006.

\section{(C) 2018 Naeimavi Majid.}

This is an open access article distributed under the terms of the Creative Commons Attribution 4.0 International Public License (CC-BY 4.0), a copy of which is available at: https://creativecommons.org/licenses/by/4.0/legalcode. This license permits unrestricted use, distribution, and reproduction in any medium, provided the original author and source are credited. 